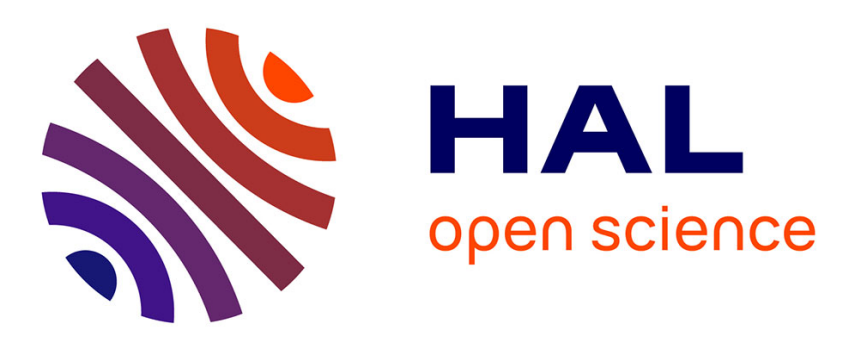

\title{
Simulation Research on Water Quality in the Irrigation Section of Jinsha River
}

\author{
$\mathrm{Xu}$ Wang, Ping Yu
}

\section{To cite this version:}

Xu Wang, Ping Yu. Simulation Research on Water Quality in the Irrigation Section of Jinsha River. 10th International Conference on Computer and Computing Technologies in Agriculture (CCTA), Oct 2016, Dongying, China. pp.354-359, 10.1007/978-3-030-06155-5_35 . hal-02179998

\section{HAL Id: hal-02179998 https://hal.inria.fr/hal-02179998}

Submitted on 12 Jul 2019

HAL is a multi-disciplinary open access archive for the deposit and dissemination of scientific research documents, whether they are published or not. The documents may come from teaching and research institutions in France or abroad, or from public or private research centers.
L'archive ouverte pluridisciplinaire HAL, est destinée au dépôt et à la diffusion de documents scientifiques de niveau recherche, publiés ou non, émanant des établissements d'enseignement et de recherche français ou étrangers, des laboratoires publics ou privés. 


\title{
Simulation Research on Water Quality in the Irrigation Section of Jinsha River
}

\author{
Xu Wang ${ }^{1(\bowtie)}$, Ping $\mathrm{Yu}^{1}$ \\ ${ }^{1}$ College of Water Conservancy Engineering, Tianjin Agricultural University, Tianjin,China \\ xuwang-82@163. com
}

\begin{abstract}
A two-dimensional water quality model is established on a section in the middle reaches of Jinsha River, based on the numerical simulation method. Considering the situation within the reach of many sewage outlets, the transport of pollutants in the river is simulated. Calculation results reveal the distribution characteristics of pollutants concentration under the effect of multi-sewage outlet discharge. The results show that the transport of pollutants along the riverside has little effect on the other side of the river. According to the predicted results, the water quality of the water intakes near the downstream reaches may not meet the standard of water quality. Therefore, the water obtained by intakes is not suitable for irrigation. It is essential to carry out effective measures to improve the water intake scheme. The paper can provide a scientific basis for the planning and design of the reasonable water intakes of the Jinsha River.
\end{abstract}

Keywords: two-dimensional water quality model; pollutant concentration; numerical simulation method; irrigation water intake.

\section{Introduction}

With the development of economy, water pollution becomes more and more serious. At present, river pollution threatens the irrigation water supply. In the middle reaches of Jinsha River, a large number of sewage outlets and some important irrigation water intakes are distributed on both sides of the river. As the sewage treatment capacity is far from meeting the requirements of the current situation, most of the untreated sewage directly discharged into the Jinsha River, which causes very adverse effects on agricultural water supply. Some scholars did a lot of researches on use of reclaimed water after sewage treatment for agricultural irrigation $[1,2]$. There are also some researches results show that although the quality of fruits and vegetables is affected by sewage irrigation, the quality of the crops will not be too poor on the basis of reasonable irrigation [3,4].In addition, analysis results of the influence of the hydraulic characteristics on water intakes are proposed from the viewpoint of hydraulics $[5,6,7,8]$. However, these researches have not taken into account the impact of water quality on the water intakes. The objective of this study is to develop a two-dimensional water quality model for simulating the concentration distribution of the pollutant in the $21 \mathrm{~km}$ section of the middle reaches of Jinsha River affected by multi-sewage outlets. Through the analysis of calculation results, it can be concluded 
whether the water quality of the irrigation water intakes meets the water quality standards. This model provides a new approach to fast and effective identification of water quality.

\section{Schemes and Methods}

\section{$2.1 \quad$ Schemes}

Many important locations exist in the area of the study reach of the Jinsha River including 48 sewage outlets, 3 irrigation water intakes and 2 monitoring sections. River profile and specific location of sewage outlets, irrigation water intakes and monitoring sections are shown in Fig. 1.

According to current situation of the river water quality monitoring data, $\mathrm{COD}_{\mathrm{Mn}}$ is used as the water quality parameter in the model. In the model, the $\mathrm{COD}_{\mathrm{Mn}}$ concentration at the entrance of the river is calculated according to the water quality monitoring data. From the river hydrological data, four characteristic flows are chosen to be simulated, which are $188 \mathrm{~m}^{3} / \mathrm{s}, 350 \mathrm{~m}^{3} / \mathrm{s}, 439 \mathrm{~m}^{3} / \mathrm{s}$ and $562 \mathrm{~m}^{3} / \mathrm{s}$.

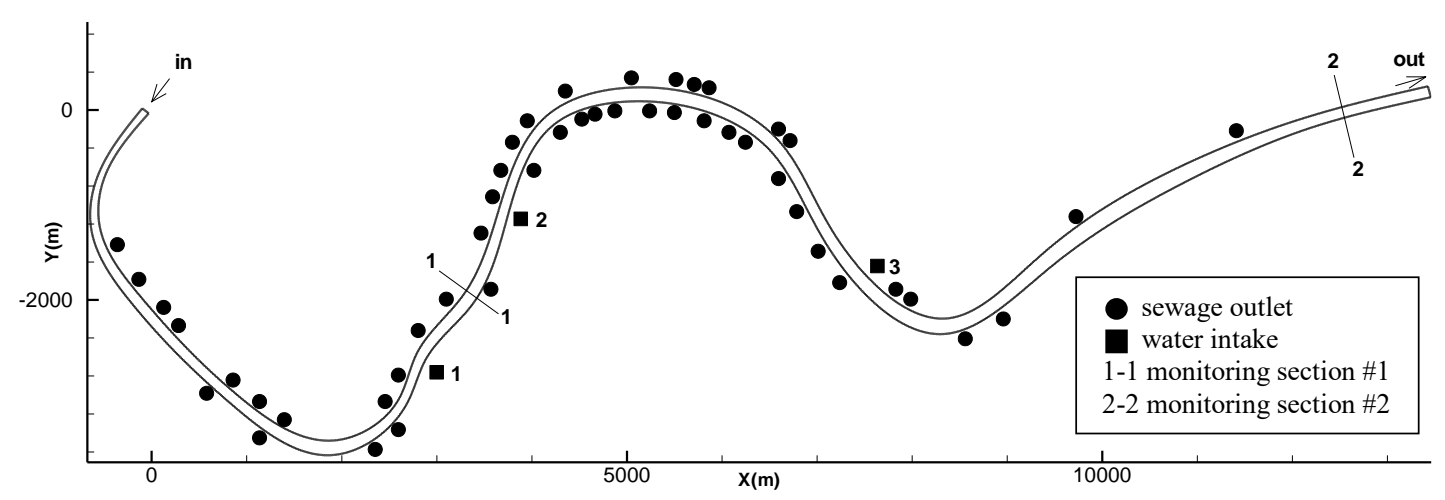

Fig. 1. Position of sewage outlets, irrigation water intakes and monitoring sections

\subsection{Methods}

This study adopts the k- $\varepsilon$ turbulence model to solve the flow field and uses the twodimensional convection diffusion model to calculate the pollutant concentration field. The discrete method and numerical solution of the model equations are solved by the finite volume method and the SIMPLE algorithm respectively. The models are validated by using the measured data of the monitoring section $\# 1$ and the monitoring section \#2.According to the measured data of $\mathrm{COD}_{\mathrm{Mn}}$, when the flow in the river is $1120 \mathrm{~m}^{3} / \mathrm{s}$, the monitoring values of $\mathrm{COD}_{\mathrm{Mn}}$ in monitoring section $\# 1$ and monitoring section $\# 2$ are $9.2 \mathrm{mg} / \mathrm{L}$ and $15.4 \mathrm{mg} / \mathrm{L}$ respectively. The calculated results of $\mathrm{COD}_{\mathrm{Mn}}$ concentration in this section are $10.5 \mathrm{mg} / \mathrm{L}$ and $18.4 \mathrm{mg} / \mathrm{L}$. Compared with the 
measured values, the error are about $14.13 \%$ and $19.48 \%$. Because the model is considered in the most unfavorable situation in which degradation of pollutants is ignored, concentration values calculated by the model are slightly larger than the measured values. In general, the model can simulate the distribution of pollutants in the river, and can be used to predict the water quality of Jinsha River.

\section{Results and Discussion}

In this paper, the numerical simulation method is used to predict the distribution of pollutant concentration in the river reach. Statistics of $\mathrm{COD}_{\mathrm{Mn}}$ concentration value of three irrigation water intake locations under different forecast conditions are shown in table 1. Because the characteristics of distribution of pollution are the same in the each condition, the distribution graphs of four typical pollution zones in condition 1 are illustrated. The concentration prediction results of $\mathrm{COD}_{\mathrm{Mn}}$ in whole reach are shown in Fig.2, local COD $\mathrm{Mn}_{\mathrm{n}}$ concentration is shown in Fig.3, $\mathrm{COD}_{\mathrm{Mn}}$ concentration distribution nearby the typical monitoring section is shown in Fig.4, COD Mn $_{n}$ concentration distribution nearby the typical water intake is shown in Fig. 5.

Table 1. Conditions statistics and calculation results

\begin{tabular}{|c|c|c|c|c|c|}
\hline \multirow{2}{*}{$\begin{array}{l}\text { Condition } \\
\text { number }\end{array}$} & \multirow{2}{*}{$\begin{array}{l}\text { Flow rate } \\
\qquad\left(\mathrm{m}^{3} / \mathrm{s}\right)\end{array}$} & \multirow{2}{*}{$\begin{array}{c}\mathrm{COD}_{\mathrm{Mn}} \\
\text { concentration } \\
\text { at model } \\
\text { entrance } \\
(\mathrm{mg} / \mathrm{L})\end{array}$} & \multicolumn{3}{|c|}{$\begin{array}{c}\mathrm{COD}_{\mathrm{Mn}} \text { concentration } \\
\text { calculation results }(\mathrm{mg} / \mathrm{L})\end{array}$} \\
\hline & & & Water intake1 & Water intake 2 & Water intake3 \\
\hline 1 & 188 & 12.52 & 14 & 14.62 & 22.94 \\
\hline 2 & 350 & 12.33 & 13.26 & 13.15 & 19.98 \\
\hline 3 & 439 & 12.29 & 13.2 & 13.06 & 19.45 \\
\hline 4 & 562 & 12.25 & 12.68 & 12.55 & 18.73 \\
\hline
\end{tabular}

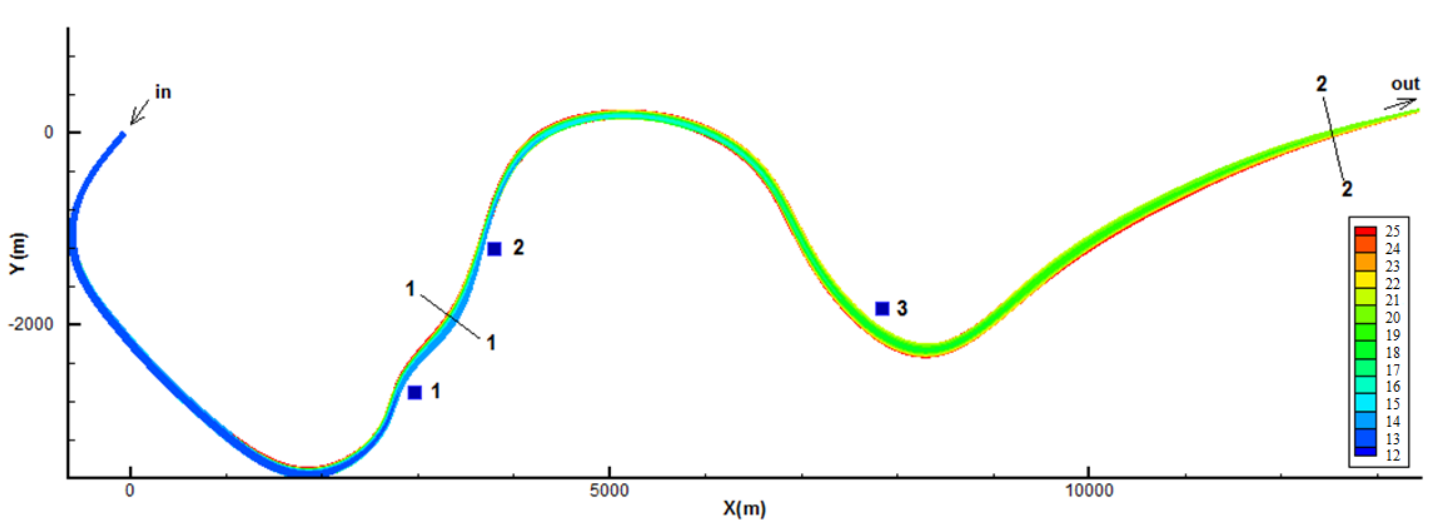

Fig. 2. Concentration distribution of $\mathrm{COD}_{\mathrm{Mn}}$ in whole reach of condition 1 (units: $\mathrm{mg} / \mathrm{L}$ ) 


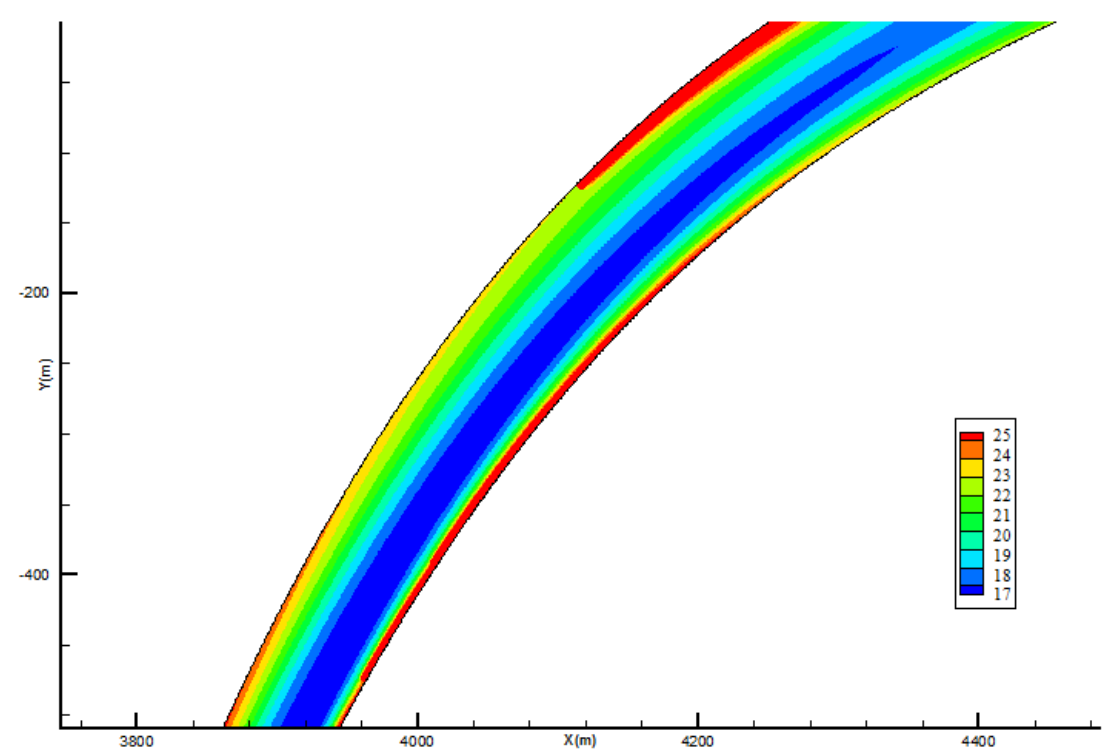

Fig. 3. Concentration distribution of $\mathrm{COD}_{\mathrm{Mn}}$ in local of condition 1 (units: $\mathrm{mg} / \mathrm{L}$ )

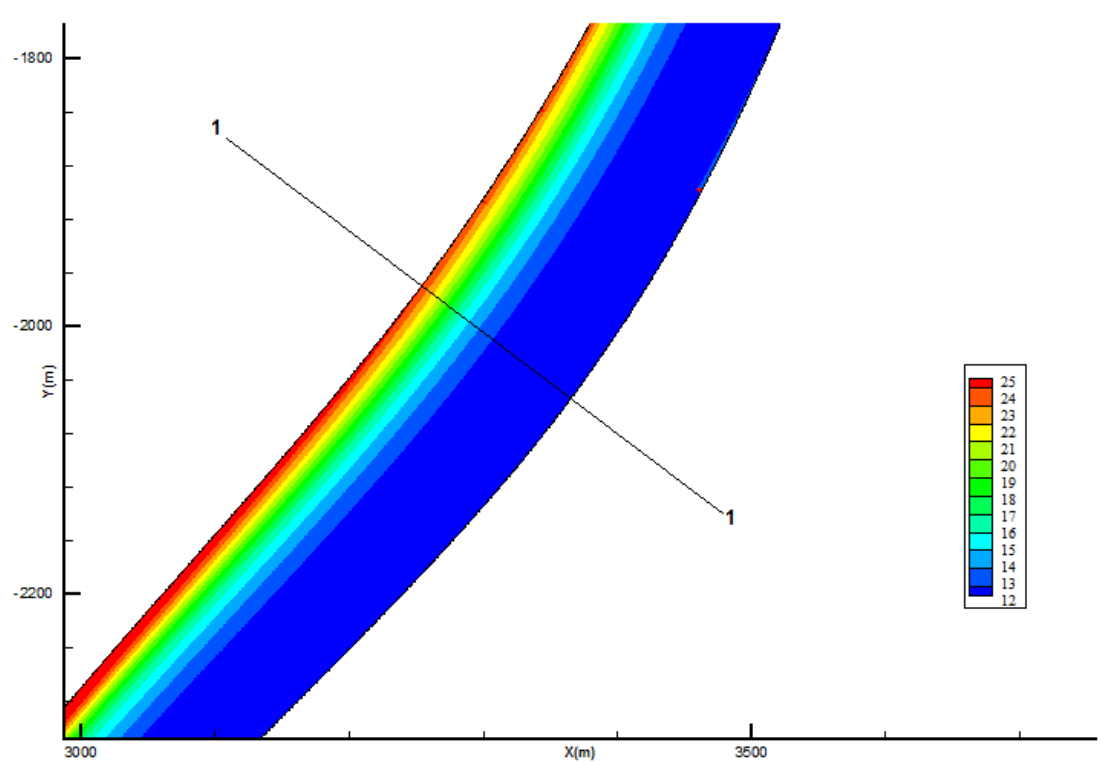

Fig. 4. Concentration distribution of $\mathrm{COD}_{\mathrm{Mn}}$ nearby monitoring section of condition 1 (units: $\mathrm{mg} / \mathrm{L}$ ) 


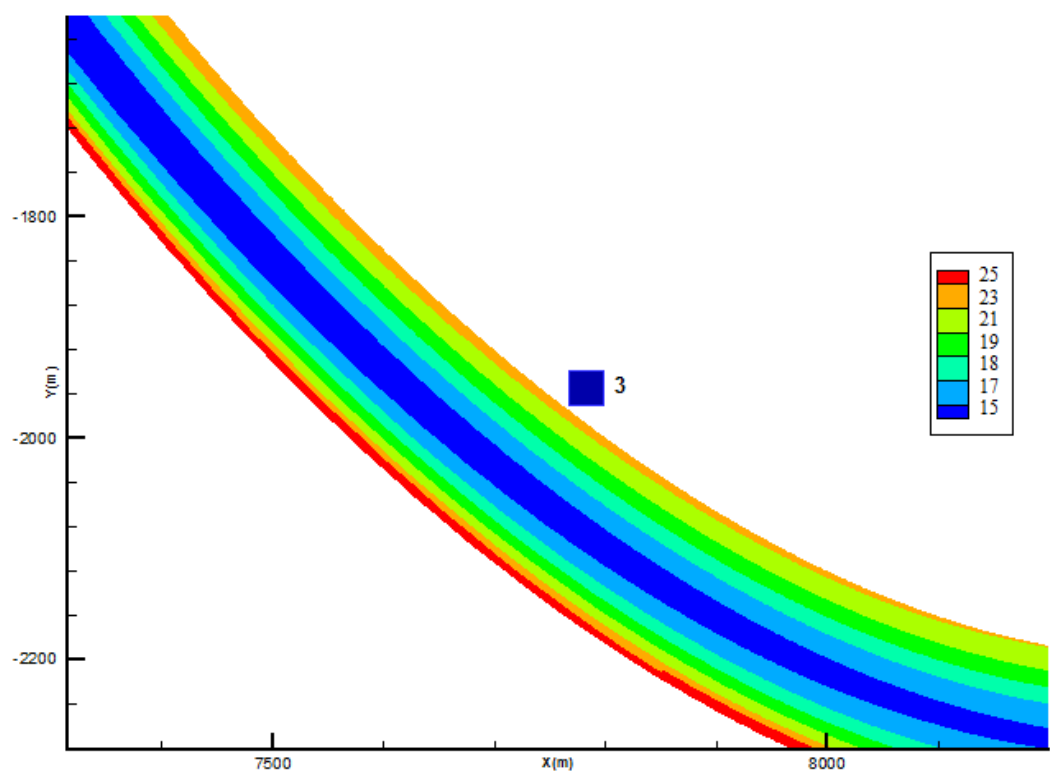

Fig.5. Concentration distribution of $\mathrm{COD}_{\mathrm{Mn}}$ nearby water intake 3 of condition 1 (units: $\mathrm{mg} / \mathrm{L}$ )

As shown in Fig.2, different colors in the figure represent different pollutant concentrations. It is obvious that the water quality is better before water intake 1 in the river reach. The concentration of pollutants in the river reach increased after water intake 2. The reason for this is that there are many sewage outlets in this section, which causes deterioration of water quality of the lower reaches of the river after the sewage superposition and coupling. The pollutant diffusion after the superposition shows in Fig.3. Because the river channel is wide, the discharge of pollutants from the sewage outlets cannot spread to the other side of the river, which leads to the uneven distribution of pollutants in the river cross section in a short distance. Fig. 4 shows that pollutants are mainly distributed on the left bank of the monitoring section. The reason for this phenomenon is the upstream sewage outlets are located on the left bank of the river, thus affecting the pollutant concentration in the left bank. Therefore, water intake 1 and water intake 2 located on the right bank nearby monitoring section \#1 are less affected by the pollution zone. Fig. 5 shows the distribution of pollutant concentration near the water intake 3 , which is an important irrigation water intake. Due to the water intake 3 is in the position of downstream river and a large number of sewage outlets locate on both sides of the river before this position, there are high concentration pollution zones nearby water intake 3 where the deterioration of water quality is serious.

From table 1, it is clear that the water quality near the water intake is relatively poor under the condition of small river flow rate. The greater the flow rate, the better the water quality near the water intake. In each condition, the concentration of pollutant in water intake 1 and water intake 2 can meet Environmental Quality Standards for Surface Water Class V requirements $\left(\mathrm{COD}_{\mathrm{Mn}}\right.$ concentration $\leqq 15 \mathrm{mg} / \mathrm{L}$ ). However, the water quality of the water intake 3 cannot 
meet the requirements. Among the conditions, the deterioration of water quality in the condition 1 is the most serious, which exceeds the standard 52.9\%. In condition 4, water quality of the water intake 3 is the best, but also exceeds the standard $24.9 \%$.

\section{Conclusions}

The study uses the $\mathrm{k}-\varepsilon$ turbulence model and the two-dimensional convection diffusion model to simulate the diffusion of water pollution in a certain section of Jinsha River. The pollutant concentration values of each position in the survey region of the four conditions are predicted. According to the calculation results of pollutants distribution characteristics, the water quality at each irrigation intake is analyzed.

The calculation results prove that the pollution belts are mainly distributed in the side of the sewage outlet, and cannot apt to spread to the other side. This is because the sewage outlets are located on both sides of the river, and the river width is larger. Therefore, the water quality in the river is better than that of the middle of the river.

Due to the concentration of pollutant in water intake 1 and water intake 2 can meet Environmental Quality Standards for Surface Water Class V requirements, water can be directly used for agricultural irrigation. But at the position of water intake 3, water quality cannot meet the water quality standards. It is essential to make water treatment before using to irrigation supply. If sewage treatment is not carried out, it is essential to optimize the water intake position. In order to obtain water quality compliance of the water, it is necessary to move the water intake from the river side to the middle of the river or other appropriate location.

\section{Acknowledgment}

Funds for this research were provided by science and technology funds from Tian jin Agricultural University (2013N13) and open cooperation funds of State Key Laboratory of Hydraulics and Mountain River Engineering Sichuan University (2016gzzx1-1)

\section{References}

1. Tavassoli A, Ghanbari A, Amiri E. Effect of municipal wastewater with manure and fertilizer on yield and quality characteristics of forage in corn. African Journal of Biotechnology. 9, 2515 -2520(2010).

2. Li Jiusheng, Li Yanfeng, Zhang Hang. Tomato yield and quality and emitter clogging as affected by chlorination schemes of drip irrigation systems applying sewage effluent. Journal of Integrative Agriculture. 11, 1744-1754(2012).

3. Calderon Preciadod, Jimenez Cartagena C, Matamoros V. Screening of 47 organic microcontaminants in agricultural irrigation waters and their soil loading. Water Research. 45, 221-231(2011). 
4. Perveen S, Samad A, Nazifw. Impact of sewage water on vegetables quality with respect to heavy metals in Peshawar pakistan. Pak .J Bot. 44, 1923-931(2012).

5. Neary V S, Sotiropoulos F. Three dimensional numerical model of lateral-intake inflow. Journal of Hydraulic Engineering ASCE. 125, 126-140(1999).

6. Jin Wei, Yang Shengfa, Zhou Huajun. Research on suspended sediment of Chuanwei inlet. Journal of Chongqing Jiaotong University:Natural Science. 26, 132-137(2007).

7. Zhao Linlin, Ma Tailing, Yu Jian. Siltation features and into canal characteristics at water intake of lateral for Yellow River irrigation area. Journal of Drainage and Irrigation Machinery Engineering (JDIME). 32, 685-690(2014).

8. Li Chao, Li Chanyou, Shen Hunk Tao. Characteristics of surface ice movement in a channel bend with intake and the layout of ice deflection booms. Advances in Water Science. 25, 233-238(2014). 